\title{
油脂および油脂食品の酸化的劣化と その評価法に関する研究
}

\author{
藤 本 健四郎 \\ 東北大学農学部応用生物化学科 (
}

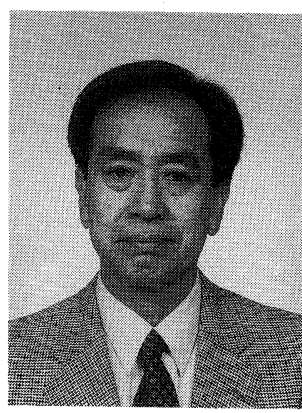

Studies on Oxidative Deterioration of Fats and Fat-Containing Foods and Deterioration Assessment

Kenshiro FuJimoto

Department of Applied Biological Chemistry, Faculty of Agriculture, Tohoku University

(1-1 Tsutsumidori-Amamiyamachi, Sendai-shi, ₹981)

\begin{abstract}
Hydroperoxides are the primary oxidation products in autoxidation of unsaturated lipids, however, in case of some types of lipids such as highlyunsaturated fatty acid-containing lipids, hydroperoxides are easily decomposed to form secondary products such as dimers. If these lipids are $\mathrm{co}^{-}$existing with other reactive ingredients such as proteins, very limited amount of hydroperoxides accumulated even lipid oxidation progressed extensively. Therefore, in these types of lipids and foods, the measurement of hydroperoxides is inadequate and alternatively determination of secondary products or the stable termination products such as protein-bound fluorescent products is preferable to assess oxidative deterioration. The oxidative stability of triacylglycerols containing highlyunsaturated fatty acids was found to be dependent on their structures, i.e., the number of highlyunsaturated fatty acids in a triacylglycerol molecule.
\end{abstract}

Key words : oxidative deterioration, hydroperoxide, lipids

\section{1 はじめに}

食品における脂質酸化反応は風味, 色の劣化を引き起 こすだけではなく，栄養の低下，ひいては過酸化脂質の 毒性と種々の観点から食品の価值を低下させる。多くの 食品には油脂以外にタンパク質など種々の成分が同時に 含まれるため, 脂質過酸化に伴う反応は脂質単独で存在 する場合と著しく様相が異なることが多い。本研究にお いてはこの点にとくに着目し，モデル系における実験か ら, 食品の脂質酸化劣化は食品の組成に応じて反応生成 物が異なるので，それぞれの場合にはふさわしい評価法 を使用することが重要であることを見いだした。また， 油脂の過酸化物が共存する食品成分や生体に対してどの ような影響を与えるかを検討した。最後に，食品中の脂 質過酸化反応はまず初めににおいの変化として感じられ るので, 油脂の初期のオフフレーバーである戻り臭発生 機構を検討した。

\section{2 高度不飽和脂肪酸含有脂質の酸化と安定性}

不飽和脂肪酸の自動酸化については，一次生成物の七 ドロペルオキシドの生成機構から揮発性二次酸化生成物 に至るまで，詳細な機構が研究されている。しかし，主 として反応の終期に生成するとされる重合物の構造につ いては生成量が多いにも係わらずほとんど解明されてい なかった。そこで, 油脂のモデルとしてリノール酸メチ ルを $30^{\circ} \mathrm{C}$ で自動酸化させ，生成物中の重合物をゲル沪 過クロマトグラフィーと TLC を併用して経時的に測定 した。その結果, リノール酸メチルの自動酸化において は, 二量体は従来の考え方とは異なり，極めて初期の段 階において，ヒドロペルオキシドに匹敵する程度に生成 することを初めて見いだした ${ }^{1)}$ (Fig. 1)。二量体を単 離して，その結合様式を調べたことろ，-C-O-O-C-結 合によっており, その主成分の構造 ${ }^{2), 3)}$ から, 二量体 がヒドロペルオキシラジカルの termination によって 生成したことが明らかになった。このことから, 酸化誘 導期におけるラジカル停止反応としての二量体生成の重 
要性を示唆した。さらに, リノール酸メチルヒドロペル オキシドを単離した後, 通気によりさらに自動酸化を進 行させたときに生ずる二量体について検討した ${ }^{4)}$ 。その 結果, 主たる二量体はリノール酸メチルの自動酸化時に 生成するものと一致することを認め, 前記のヒドロペル オキシラジカル同士の反応による二量体に形成が裏付け られた (Fig. 2)。さらに，この場合に-C-O-C-のよう にヒドロペルオキシドから生成したアルコキシラジカル 由来と考えられる成分が検出された。また, リノレン酸 メチルおよびそのヒドロペルオキシドについても同様に 検討し二量体の構造を解析したが, リノレン酸において は単量体ですでに認められている環状構造を持つ二量体
が生成した ${ }^{5)}$ (Fig. 3)。このようにして生成した二量 体は非常に不安定で, 容易に分解して低分子分解物を与 え, 酸化臭の原因となることが分かった ${ }^{6)}$ 。本実験にお いて使用したリノール酸メチルヒドロペルオキシドは, 自動酸化リノール酸メチルからシリカゲルドライカラム クロマトグラフィーによって調製できた7)。

また，特異な生理活性が注目されている $n-3$ 系高度 不飽和脂肪酸が酸化しやすいことはよく知られている が, どの程度速いのか，また酸化生成物にはどのような 特徵があるかといったことは不明であった。そこでま ず, イコサペンタエン酸 (EPA) およびドコサへキサエ ン酸 $(\mathrm{DHA})$ のエチルエステルを調製し, $5^{\circ} \mathrm{C}$ に保存し

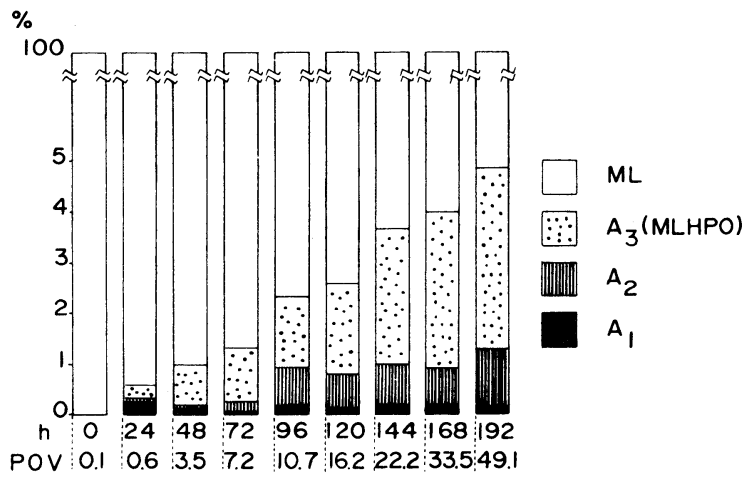

Fig. 1 Quantitative Analysis of Autoxidized Methyl Linoleate by Photodensitometer.

Percentage distribution of each component $\left(A_{1}, A_{2}, A_{3}\right.$, $\mathrm{ML})$ was calculated from the peak area on densitograms.

$\mathrm{A}_{1}$ and $\mathrm{A}_{2}$ are dimers.
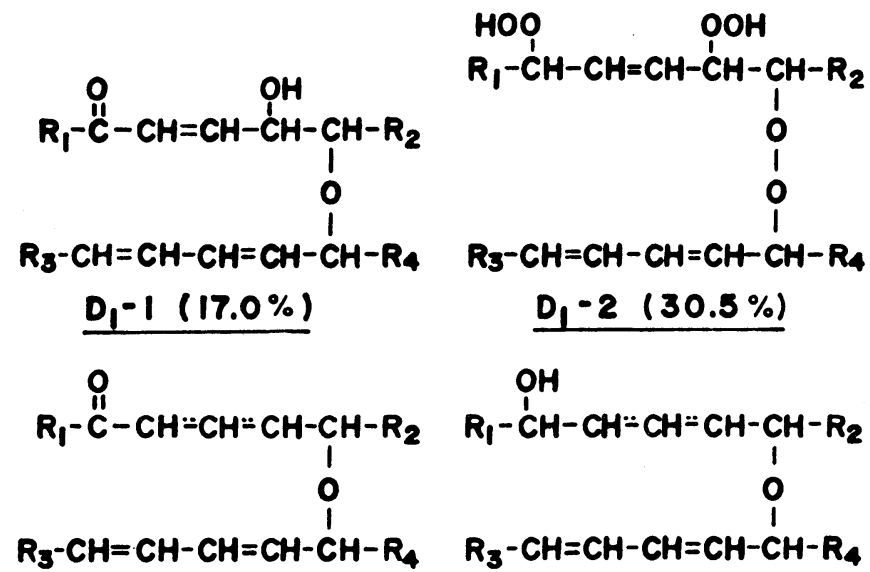

$$
\frac{D_{2}-1(4.2 \%)}{R_{1}, R_{2}, R_{3}, R_{4}}=-\left(\mathrm{CH}_{2}\right)_{4} \mathrm{CH}_{3} \text { or }-\left(\mathrm{CH}_{2}\right)_{7} \mathrm{COOCH}_{3}
$$

Fig. 2 Structures of Major Dimers Identified in Oxygenated Methyl Linoleate at $30^{\circ} \mathrm{C}$. 
A

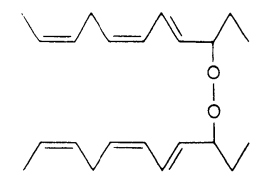

B
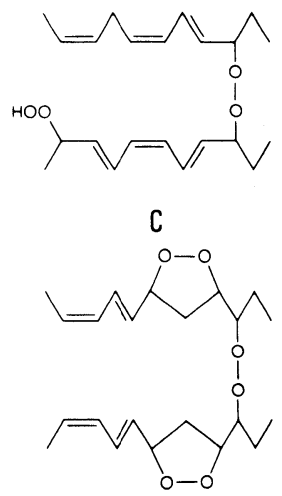

Fig. 3 Main Structures of Peroxide-linked Dimers Formed by Autoxidation of Methyl Linolenate at $40^{\circ} \mathrm{C}$.
たときの酸化の進行を酸素吸収により測定した ${ }^{8)}$ 。 DHA および EPA エチルエステルは，約 $2 \mathrm{~d}$ の誘導期 の後に急速に酸素を吸収し，その速度はリノレン酸エチ ルのそれぞれ 5.2 および 8.5 倍だった。本条件ではリ ノール酸は非常に安定で, 3 週間の保存中に酸素を吸収 しなかった。

これらの高度不飽和脂肪酸ではヒドロペルオキシドの 安定性が悪いため, Fig. 4 に見られるように酸化初期か ら二次生成物が著量生成し, リノール酸酸化と生成物の パターンが大きく異なることが明らかになった ${ }^{8)}$ 。ま た, これらの脂肪酸エチルを蛍光灯下で保存すると, DHA や EPA にはもはや酸化誘導期は認められず，連 鎖反応期の酸化速度はリノール酸エチルのそれぞれ 1.9 および 2.3 倍, リノレン酸エチルの約 1.1 および 1.4 倍 だった ${ }^{9)}$ 。このように, 高度不飽和脂肪酸の自動酸化に おいては, リノール酸酸化と異なり, 酸化初期から重合 物をはじめとする二次生成物の比率が高いので, 吸収さ れた酸素のうち過酸化物価で定量されるヒドロペルオキ シ酸素の比率が酸化初期から 60〜 70\% 以下と低く, と くに酸化中期以降では過酸化物価が減少するので, 過酸 化物価を指標とするのはあまり適当ではなかった。

高度不飽和脂肪酸は通常, 魚油などではトリアシルグ リセリンの形で存在している。そのトリアシルグリセリ ン分子での高度不飽和脂肪酸の分布はランダムではな

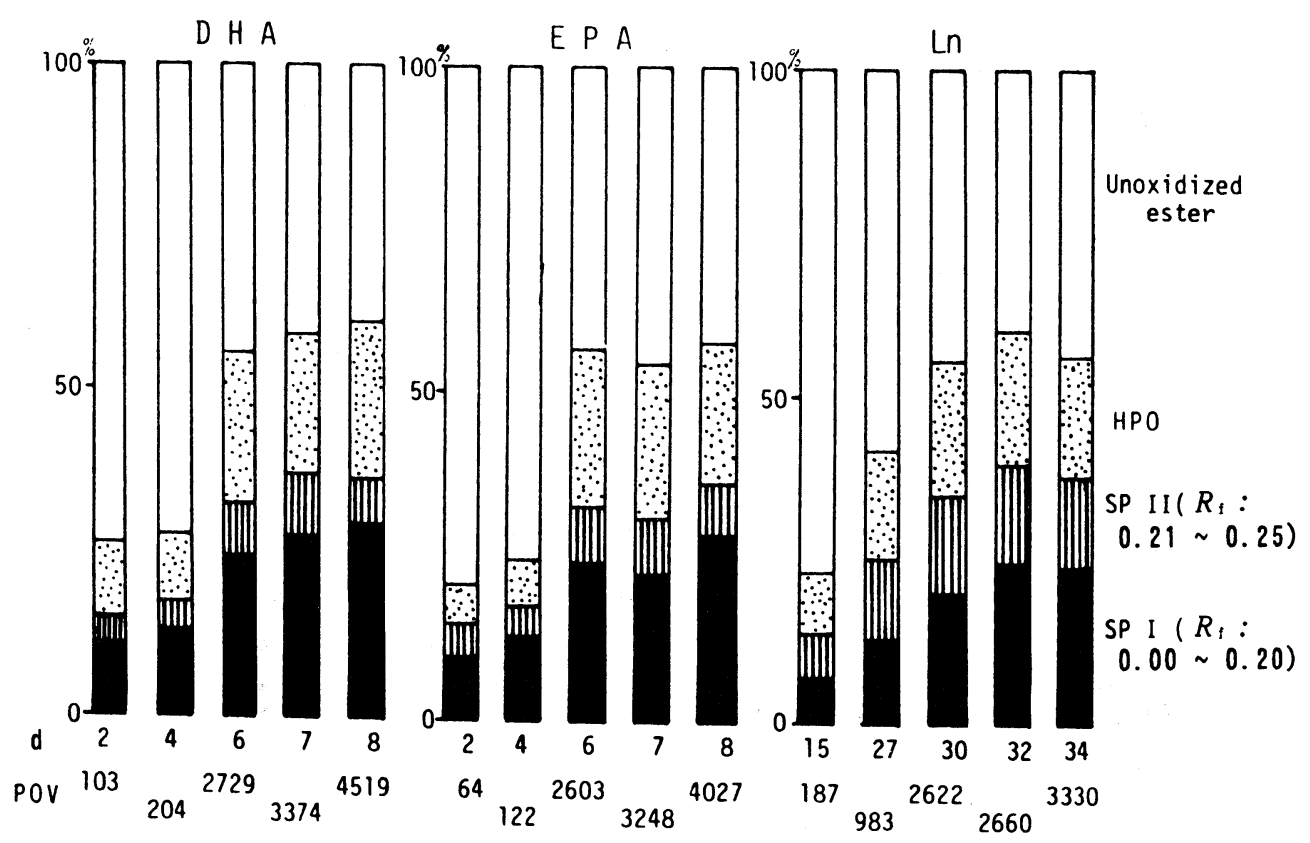

Fig. 4 Quantitative Analysis Ethyl Linolenate, EPA and DHA Autoxidized at $5^{\circ} \mathrm{C}$ in the Dark.

Ln : linolenate ; HPO : hydroperoxide ; SP I : secondary products (bifunctional monomers) ; SP II : secondary products (dimers). 


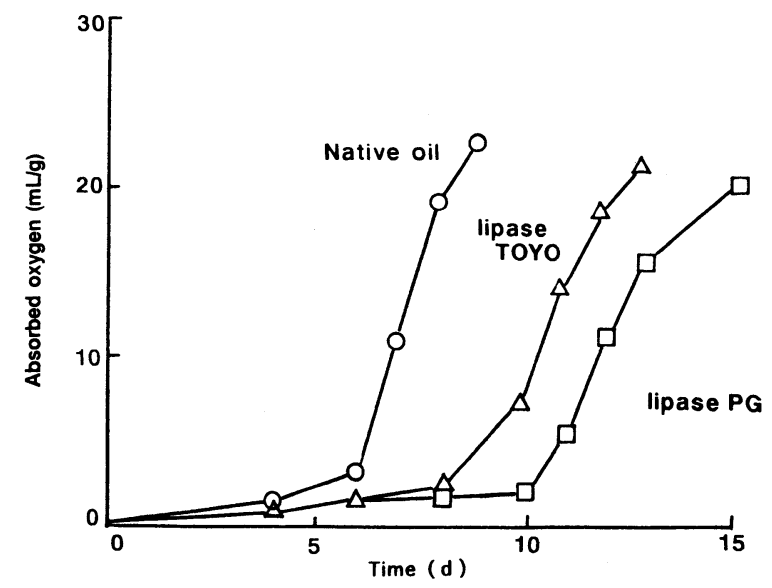

Fig. 5 Changes in Level of Oxygen Absorbed during Autoxidation of Native and Enzymatically Interesterified Sardine Oils at $40^{\circ} \mathrm{C}$.

( $\bigcirc)$ Native oil ; $(\triangle)$ lipase TOYO-interesterified oil ; $(\square)$ lipase PG-interesterified oil.

く,イワシ油のような魚油では, DHA は高選択的に $s n-2$ 位に分布し, EPA も $s n-2$ 位に多いが DHA より は 2 位への分布の割合は低く, 同一分子中に複数の高度 不飽和脂肪酸を含む高度に不飽和な分子が存在している ことが知られている ${ }^{10)}$ 。一方, 鯨油などの海洋ほ(哺) 乳動物油脂では, 高度不飽和脂肪酸は $s n-2$ 位よりむし ろ 1-または 3 -位に選択的に分布することが報告されて

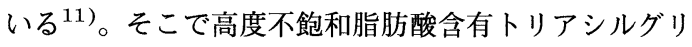
セリンの酸化安定性と構造との関係を検討するため, 魚 油や鯨油を化学触媒あるいは酵素を用いてエステル交換 して酸化安定性に与える影響を比較した。イワシ油など の魚油はランダム化によって酸化安定性が向上し (Fig. 5), 鯨油では逆に安定性が悪くなった ${ }^{12)}$ (Fig. 6)。ま た, 魚油を種々の脂肪酸とアシドリシスすると, 飽和ま たはモノエン酸の場合には安定性は向上し，とくにオレ イン酸の効果が優れていた ${ }^{13)}$ (Fig. 7)。これらの結果 から, 高度不飽和脂肪酸を含むトリアシルグリセリンの 酸化安定性は分子構造に依存し, 高度不飽和脂肪酸を複 数, とくに分子内で隣接する位置に含むと安定性が著し く劣ることが示唆された。そこで, EPA およびパルミ チン酸からなる各種トリアシルグリセリンを化学的に合 成してその酸化安定性を種々の条件下で比較した。

Fig. 8, 9 にはベンゼン中, ラジカル開始剤 AMVN の 存在下で酸素吸収速度から安定性を比較した結果を示し たが，酸化安定性には同一トリアシルグリセリン分子中 の EPA のモル数が最も大きく影響し, EPA のモル数 が同じ場合には，隣接する位置に存在すると安定性が悪 くなることが明らかになった。従って, EPA とパルミ チン酸が $1: 2$ で存在する場合には, 酸化速度は EEE/ $\operatorname{PPP}(1: 2)>\operatorname{EEP} / \mathrm{PPP}(1: 1)>\operatorname{EPE} / \mathrm{PPP}(1: 1)>$

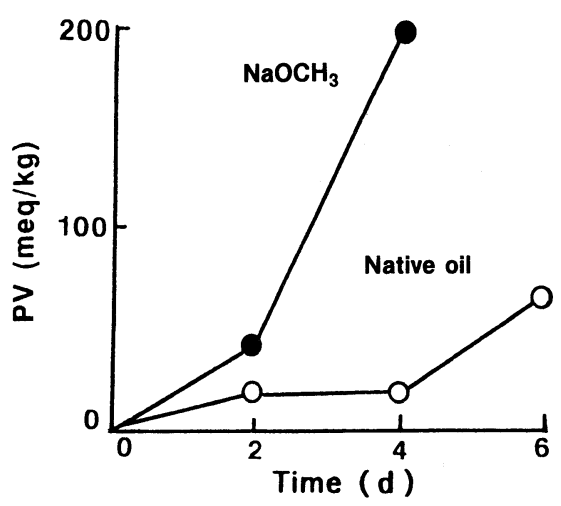

Fig. 6 Changes in Peroxide Value (PV) of $\mathrm{Na}$ tive and Chemically Interesterified Mink Whale Blubber Oils during Autoxidation at $40^{\circ} \mathrm{C}$.

(○) Native oil ; (O) interesterified oil.

EPP の順だった ${ }^{14)}$ 。トリアシルグリセリンを水中に分 散させ, AAPH 存在下で酸化した場合にもほぼ等しい 結果を得た ${ }^{14)}$ 。このトリアシルグリセリンの酸化安定 性の差は, 主として生成した脂質ラジカルの連鎖反応回 数に依存していることが明らかになった ${ }^{15)}$ 。また, ラ ジカル開始剤を加えずにトコフェロールを添加して酸化 誘導期の長さから酸化安定性を比較しても, Fig. 10, 11 のようにほぼ上記の結果と一致した ${ }^{16)}$ 。さらに EPA の 代わりにDHA を用いても, 酸化安定性に与えるトリ アシルグリセリン構造の影響は同じ結果が得られた。酸 化安定性から考えると, 高度不飽和脂肪酸を高度に濃縮 するのは望ましくないことが明らかになった。 


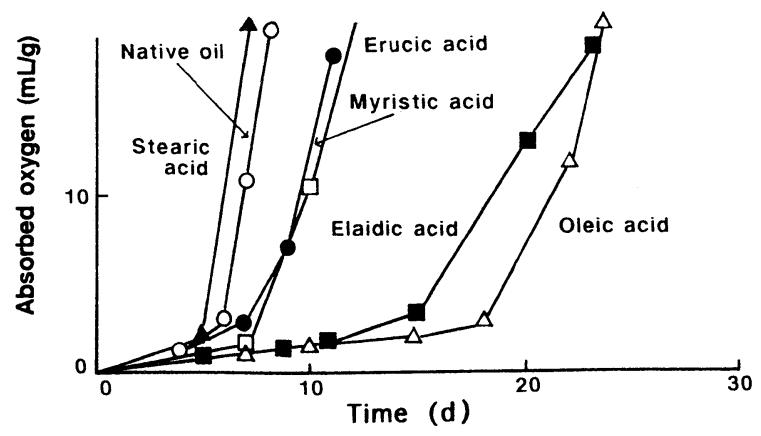

Fig. 7 Oxidative Stability of Sardine Oil Samples Modified by Acidolysis with Saturated and Monounsaturated Fatty Acids.

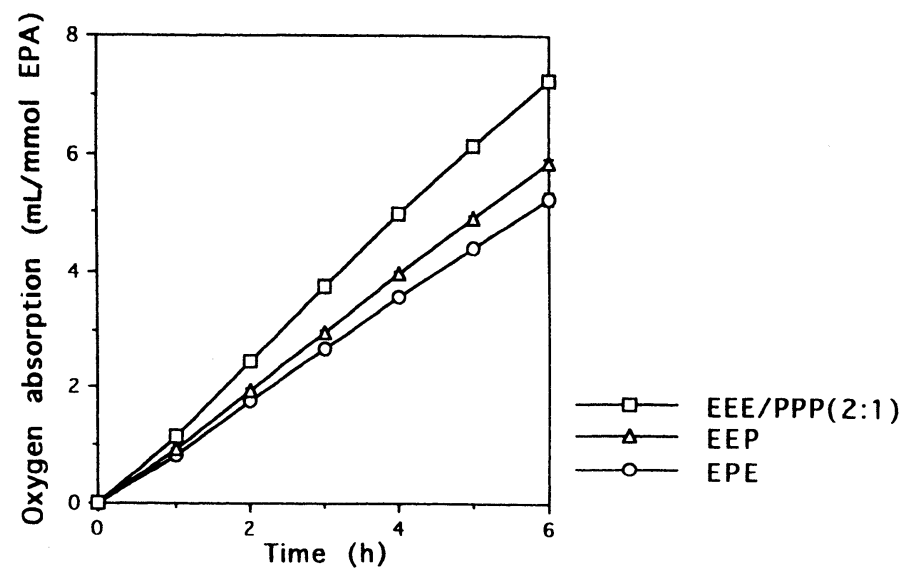

Fig. 8 Oxygen Absorption of Triacylglycerols Containing Icosapentaenoic Acid and Palmitic Acid $(2: 1)$ during AMVN-initiated Oxidation at $37^{\circ} \mathrm{C}$.

(E) icosapentaenoic acid; (P) palmitic acid.

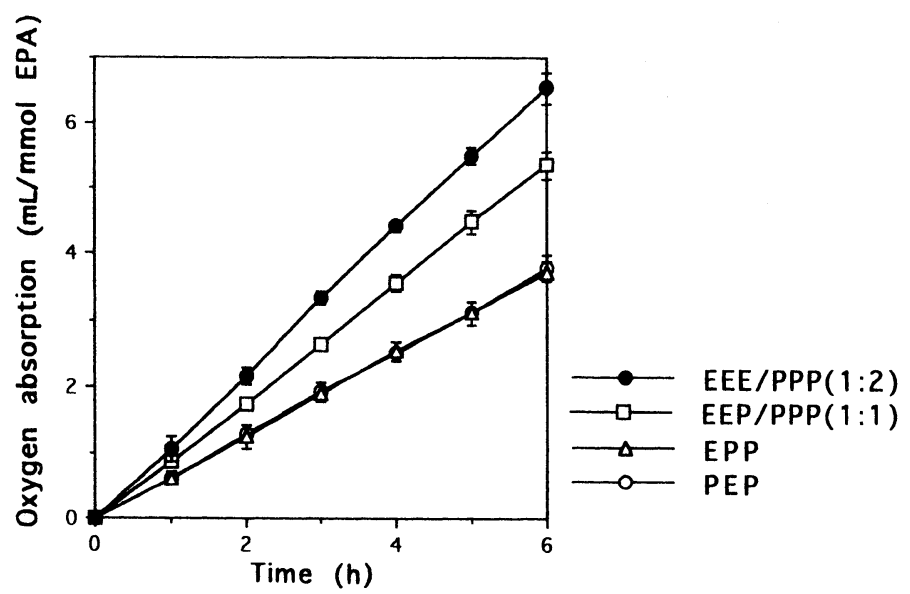

Fig. 9 Oxygen Absorption of Triacylglycerols Containing Icosapentaenoic Acid and Palmitic Acid (1:2) during AMVN-initiated Oxidation at $37^{\circ} \mathrm{C}$.

(E) icosapentaenoic acid ; $(\mathrm{P})$ palmitic acid. 


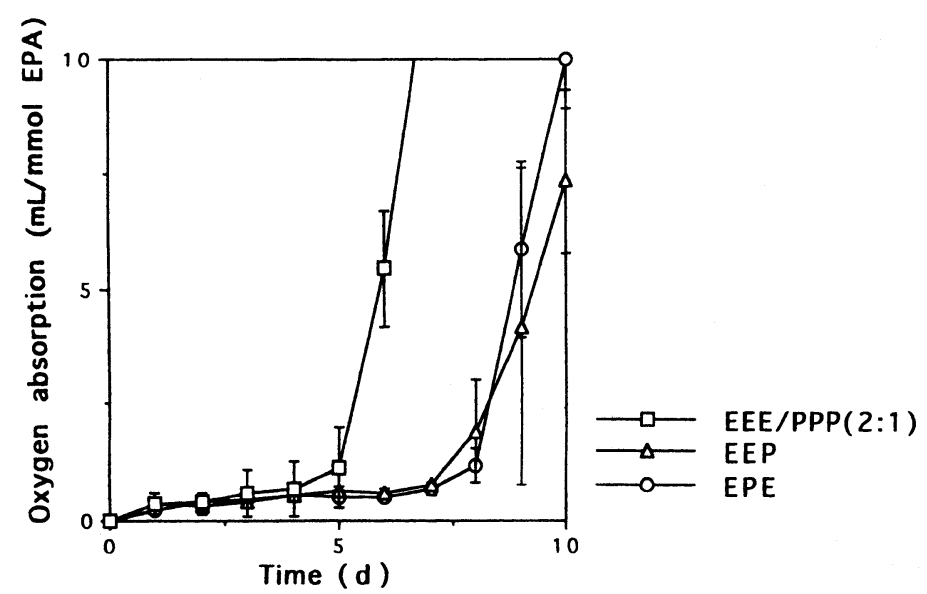

Fig. 10 Oxygen Absorption of Triacylglycerols Containing Icosapentaenoic Acid and Palmitic Acid $(2: 1)$ during Autoxidation at $25^{\circ} \mathrm{C}$.

(E) icosapentaenoic acid; (P) palmitic acid. $\alpha$-Tocopherol was added at a $0.1 \%$ level.

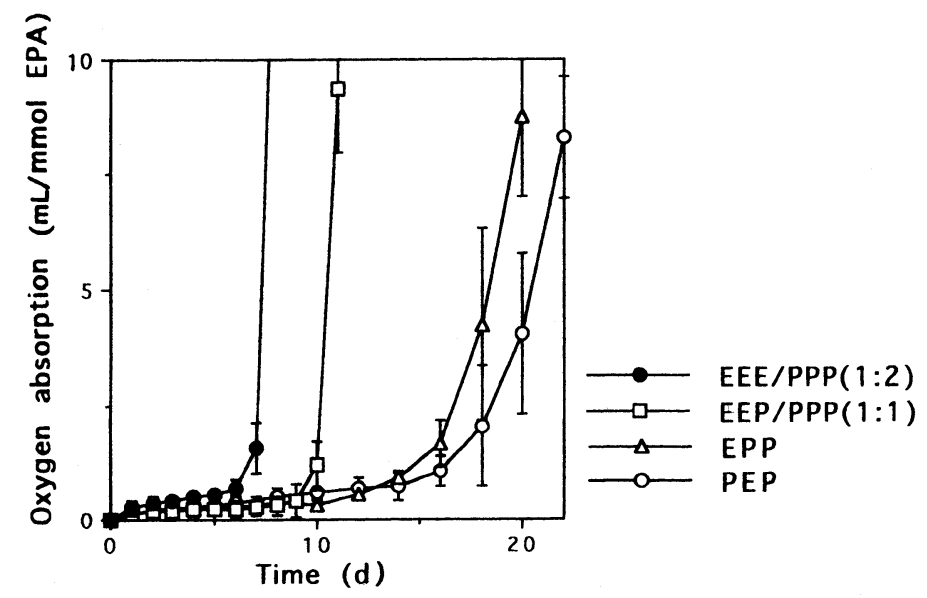

Fig. 11 Oxygen Absorption of Triacylglycerols Containing Icosapentaenoic Acid and Palmitic Acid $(1: 2)$ during Autoxidation at $25^{\circ} \mathrm{C}$.

(E) icosapentaenoic acid ; (P) palmitic acid. $\alpha$-Tocopherol was added at a $0.1 \%$ level.

\section{3 脂質および油脂を含む食品中の酸化 生成物の特徵とその劣化評価法}

脂質ヒドロペルオキシドの微量定量法にはいくつかの 方法が提案されているが，われわれはリン脂質ヒドロペ ルオキシドをへムタンパク質とルミノールからなる発光 試薬と反応させる化学発光検出法を開発し17), 生体中 の微量なヒドロペルオキシドの測定に応用した。化学発 光検出器を用いる脂質劣化の評価としては, このほか魚 肉ホモジネートの微弱発光からの鮮度および酸化安定性 の評価を試みた ${ }^{18)}$ 。しかし, 高度不飽和酸含有脂質,
リン脂質などではヒドロペルオキシドの安定性が悪く, 例えばイワシ油とマイワシ脱脂タンパク質から構成した モデル系を $5^{\circ} \mathrm{C}$ で保存すると, 初期には過酸化物価が上 昇するものの 1 週間以内に減少に転じ，消費された全酸 素中, 過酸化物価で測定できる酸素は, 初期で約 $60 \%$, 1 週間後では $30 \%$ 以下であり，こうした食品の酸化的 劣化の評価には過酸化物価は不適なことを明らかにし た ${ }^{19)}$ 。実際の塩干マイワシを冷蔵した場合でも, 酸素 吸収の割には過酸化物価は上昇せず，また初期において はリン脂質の酸化が顕著であり, 組織別に見ると皮部で の酸化が極めて速かった ${ }^{20)}$ 。マイワシ皮の脂質酸化促 
進物質は熱に不安定なへムタンパク質であり, リノール 酸から 13-S-ヒドロペルオキシドを選択的に生成するリ ポキシゲナーゼの活性を有していた ${ }^{21), 22)}$ (Fig. 12)。

さらに過酸化物を蓄積しない極端な例としてはオキア ミがあげられる。オキアミの脂質含量は少ないもののそ の約半分がリン脂質であり, 高度不飽和脂肪酸に富んで
いる。しかし，オキアミを室温に保存しても過酸化物価 は全く上昇せず，あたかも非常に脂質が安定なように見 える23)。しかし, カルボニル価を測定すると, 保存中 に著しく増加することから, 高度不飽和脂肪酸含有リン 脂質では, とくにヒドロペルオキシドの安定性が悪く ${ }^{24)}$ (Fig. 13), リン脂質ヒドロペルオキシドの分解で生じ
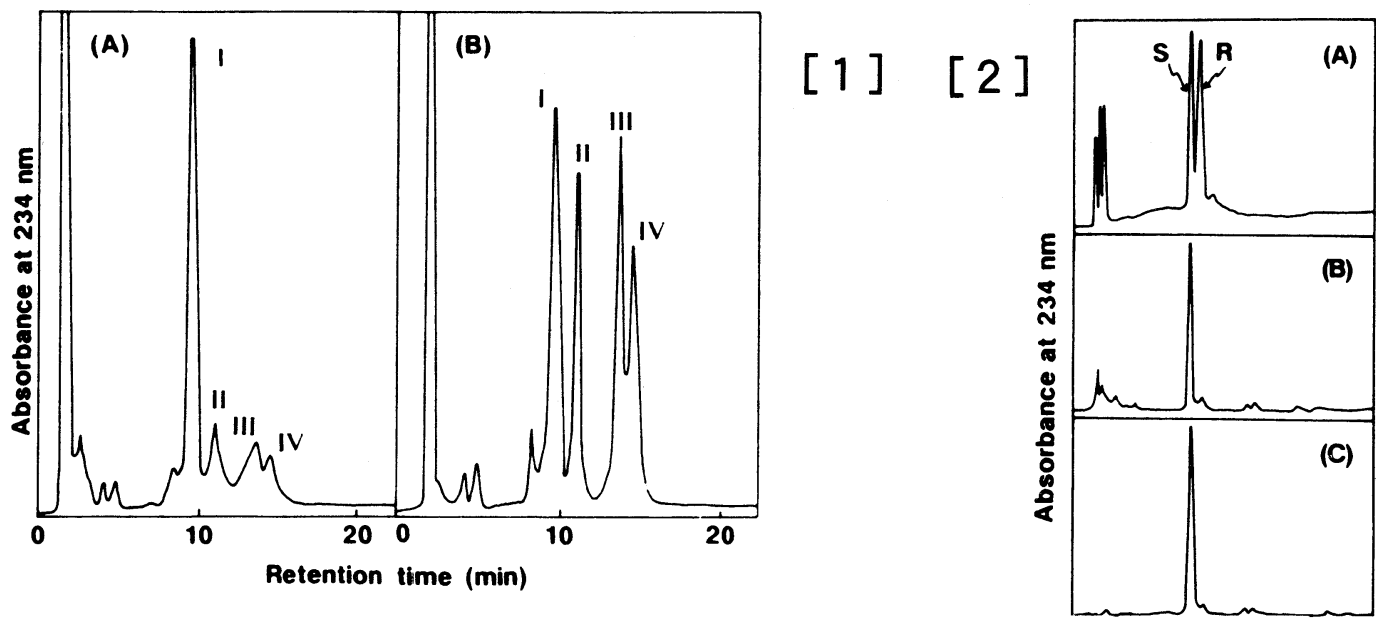

Fig. 12 Analyses of Positional and Steric Isomers of Methyl Hydroxyoctadecadienoate Derivatives Produced by Sardine Skin Lipoxygenase and Autoxidation.

[1] Positional isomers. (A) Sardine skin lipoxygenase ; (B) Autoxidation. ( I ) 13OOH-9Z,11E ; ( II ) 13-OOH-9E,11E ; ( III ) 9-OOH-10E, 12Z ; (IV) 9-OOH-10E,12E.

[2] Steric isomers of 13-OOH-9Z, 11E. (A) Autoxidation ; (B) Sardine skin lipoxygenase ; (C) Soybean lipoxygenase (L-1).
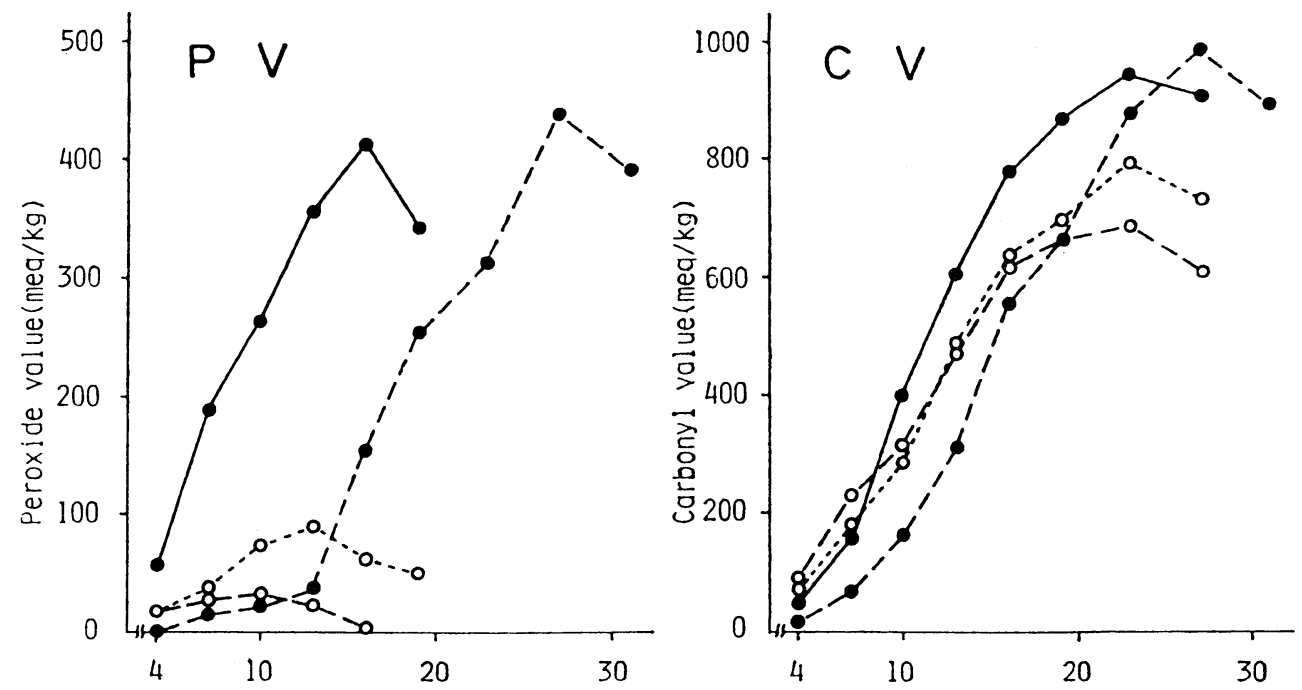

Fig. 13 Effect of Additive Polar Lipids on Peroxide Value (PV) and Carbonyl Value (CV) of Neutral Lipids in Krill during Storage at $45^{\circ} \mathrm{C}$.

Neutral lipids were mixed with polar lipids according to the ratio in total lipids.

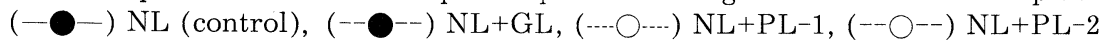
NL : Neutral lipids ; GL : Glycolipids ; PL : Phospholipids. 
た褐変物に強いヒドロペルオキシド分解作用があること を見いだした ${ }^{25) 。 ~}$

このようにヒドロペルオキシドの安定性が悪い油脂食 品では劣化評価には酸化二次生成物の測定が勧められる が，とくに脂質過酸化物と反応しやすい夕ンパク質を多 く含む食品では劣化評価にはむしろ安定な最終生成物の 定量が望ましく, その例としてタンパク質結合型の蛍光 の測定による酸化的劣化評価法を開発した。モデル食品 としてイワシ油および脱脂マイワシタンパク質を混合し て魚粉を調製し, 酸素吸収量を対照に過酸化物価, TBA 値, 有機溶剤可溶性蛍光およびタンパク質結合型 蛍光を $25^{\circ} \mathrm{C}$ において経時的に測定した。その結果, Fig. 14, 15 に示したように, 過酸化物価, TBA 值, 有 機溶剂可溶性蛍光はいずれも保存 $3 \sim 5 \mathrm{~d}$ に極大に達 し, その後, 減少に転じた。従って, これらの特数は極 めて初期以外は酸化的劣化の評価指標としては不適だっ た ${ }^{24)}$ 。一方, 有機溶剤に不溶なタンパク質結合型蛍光

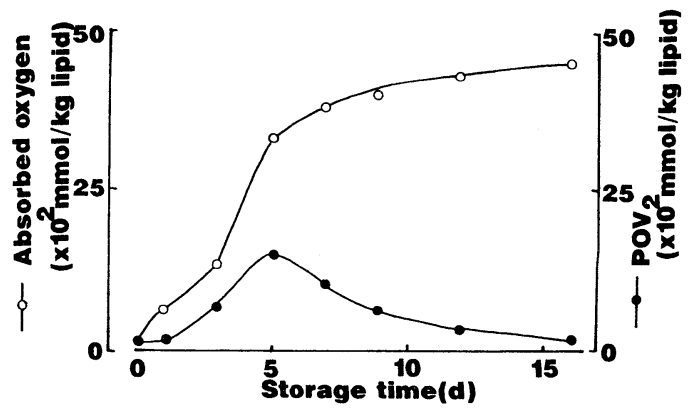

Fig. 14 Time Course of Oxygen Absorption and Peroxide Value (PV) during Storage of Fish Model System at $25^{\circ} \mathrm{C}$ in the Dark.

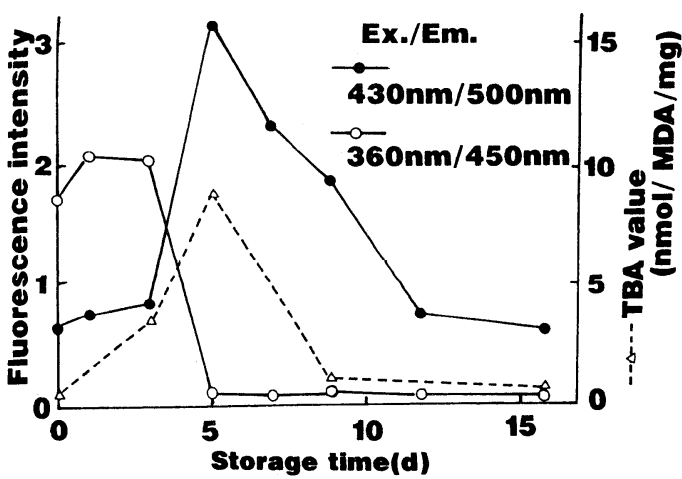

Fig. 15 Time Course of Thiobarbituric Acid (TBA) Value and Fluorescence Intensity of $\mathrm{CHCl}_{3} / \mathrm{MeOH}(2: 1)$ Extracts from Fish Model System Stored at $25^{\circ} \mathrm{C}$ in the Dark.
はスペクトルの異なる 2 種 I (ex. $370 \mathrm{~nm}, \mathrm{em} .460$ $\mathrm{nm})$ および II (ex. $450 \mathrm{~nm}, e m .500 \mathrm{~m})$ が観察され (Fig. 16), いずれも保存日数の経過とともに上昇し た ${ }^{26)}$ (Fig. 17)。蛍光 Iにはメイラード反応の影響が見 られたが, 蛍光 II は酸素吸収と極めてよい相関を与えた ので (Fig. 18), 脂質の酸化に伴うタンパク質含有食品 の劣化指標として優れていると考えられる ${ }^{26)}$ 。この方 法は魚粉に限らず, 卵黄粉末, 凍結乾燥豚肉 27 ), きな こや凍り豆腐などの大豆製品 ${ }^{28)}$, 魚の干物 ${ }^{29)}$ の劣化評 価に応用できた。

また, 過酸化物を含む油脂の酸化フレーバーの指標あ るいはフライ油の劣化指標となるカルボニル価の測定法 として, 従来からの $\mathrm{SnCl}_{2}$ 還元法に比較して特別な抽 出操作が不要で操作の簡便なトリフェニルホスフィン還

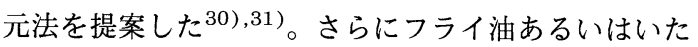
(炒)め油などの高温加熱油の劣化評価法についても検討 し, 熱酸化で生ずる主成分が極性の高い重合物である点 に着目し, ゲル沪過カラムによる二量体あるいは TLCFID による高極性物質の定量が優れた評価法であるこ とを明らかにし ${ }^{32)}$, ジャガイモを揚げた大豆油の評価 を行った ${ }^{33)}$ 。

\section{4 食品中の抗酸化性物質}

高度不飽和脂肪酸あるいはカロテノイド色素などの容 易に酸化しやすい成分を含むにもかかわらず酸化安定性 のよい食品があることに着目し，その安定化に役立って いる抗酸化性物質を明らかにした。トウガラシはカロテ ノイドのカプサンチンのために赤色を呈するが，乾燥状

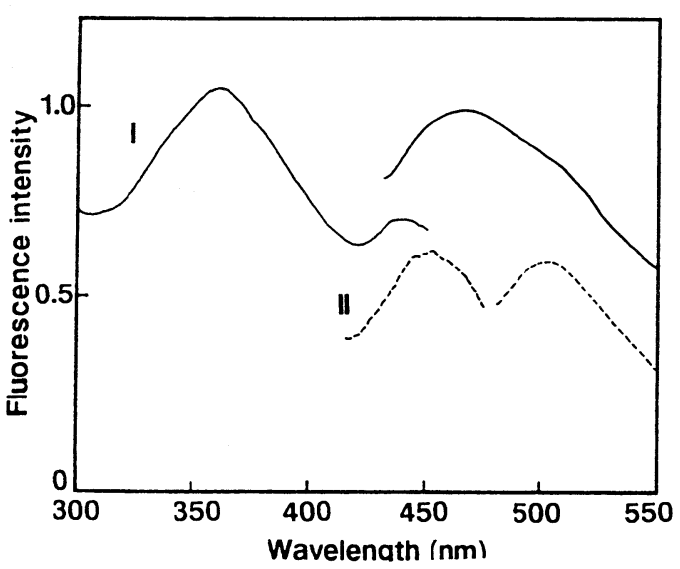

Fig. 16 Excitation and Emission Spectra of Fish Model System by Solid Sample Spectrofluorometry. For obtaining the spectra, excitation/emission wavelengths were set at $370 \mathrm{~nm} / 460 \mathrm{~nm}$ for fluorescence I, and $450 \mathrm{~nm} / 500 \mathrm{~nm}$ for fluorescence II . 


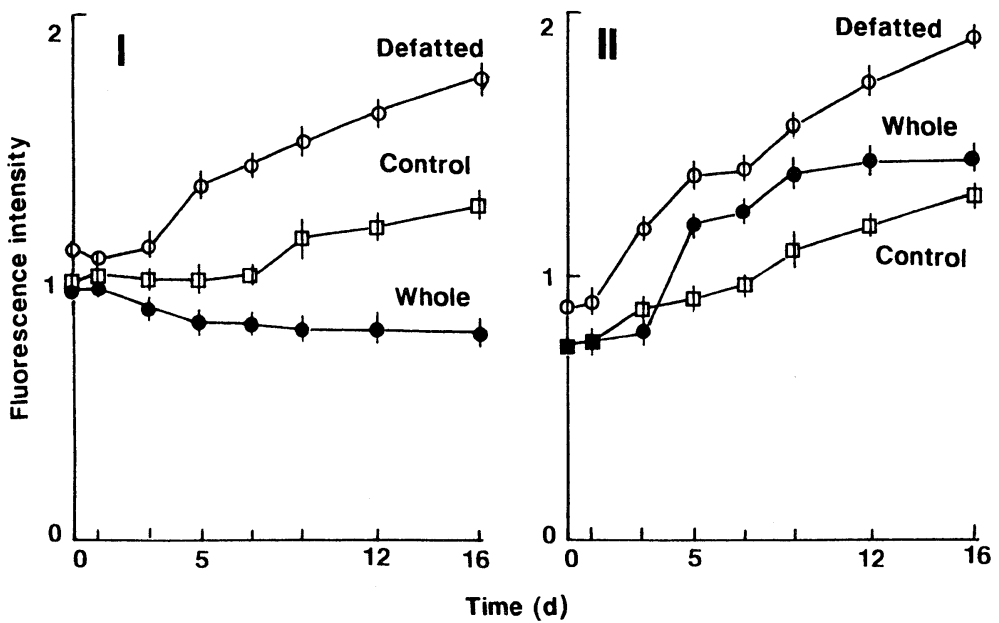

Fig. 17 Time Course of Intensity of Fluorescence I (ex. $370 \mathrm{~nm}$, em. 460 $\mathrm{nm})$ and II (ex. $450 \mathrm{~nm}$, em. $500 \mathrm{~nm})$ by Solid Sample Spectrofluorometry of Fish Model System Stored at $25^{\circ} \mathrm{C}$ in the Dark.

(O) whole (before lipid extraction); $(\bigcirc)$ defatted (after lipid extraction) ; $\square$ ) control (stored without lipids).

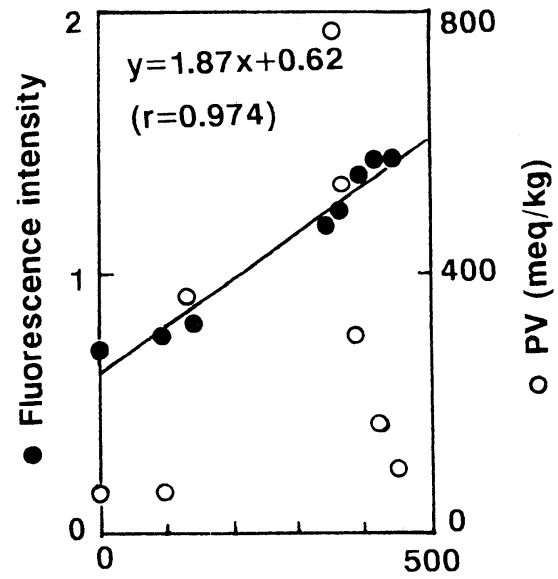

Absorbed oxygen ( $\mathrm{nmol} / \mathrm{g})$

Fig. 18 Relationship of Fluorescence II Intensity $(\mathrm{O})$ or Peroxide Value (PV) $(\mathrm{O})$ to $\mathrm{Ab}$ sorbed Oxygen during Storage of Fish Model System at $25^{\circ} \mathrm{C}$.

Fluorescence intensity and the peroxide value were plotted against the amount of absorbed oxygen.

態でもその色を長期間よく保持している。そこで，トウ ガラシ中の抗酸化性物質を調べ, トコフェロールととも に辛味物質であるカプサイシン類が有効であることを見 いだした ${ }^{34)}$ 。カプサイシンは強い辛味を持つため抗酸 化物質としての用途が限られるが，カプサイシンのよう なバニリルアミドの辛味は構成する脂肪酸の鎖長に依存
することに着目し，辛味はほとんどないが抗酸化性を有 する長鎖脂肪酸誘導体の合成を行った ${ }^{35)}$ 。また, 海藻 中の脂質含量は低いが，構成脂肪酸としては高度不飽和 脂肪酸含量が高いにもかかわらず乾燥状態でも比較的に

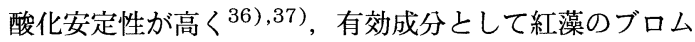
フェノール類 ${ }^{38), 39)}$ その他をを見いだし, 生体内での抗 酸化性についても検討した ${ }^{40)}$ 。

さらに, 高度不飽和脂肪酸が極めて多いため非常に酸 化が進みやすい魚粉において，製造中のエキス (stick water) の濃縮工程で少量のグルコースを加えることに より Maillard 反応を起こし，ジゼロシンの前駆体であ るヒスタミンを減少させ, タンパク質の必須アミノ酸を 損なうことなく酸化安定性を著しく高めることに成功し $た^{41)}$ (Fig. 19)。

また，疎水性タンパク質は低水分系では共存する不飽 和脂質の安定性を高めることが知られているが，卜ウモ ロコシのゼインのリノール酸メチル安定化機構について 検討し, タンパク質の疎水的な構造とともに少量含まれ るフェノール系抗酸化性物質が重要であることを明らか にし 42),43), これらのタンパク質はエマルション系でも 有効なことを見いだした ${ }^{44)}$ 。

\section{5 過酸化脂質と食品成分との相互作用 ならびに生体への影響}

過酸化脂質は, フリーラジカルの生成する条件下で DNA と反応し，強い蛍光を生ずることを見いだし ${ }^{45)}$, その反応機構が主として核酸のアデニン部分との反応に よることを明らかにし ${ }^{46), 47)}$, 主要な蛍光物質の構造を 


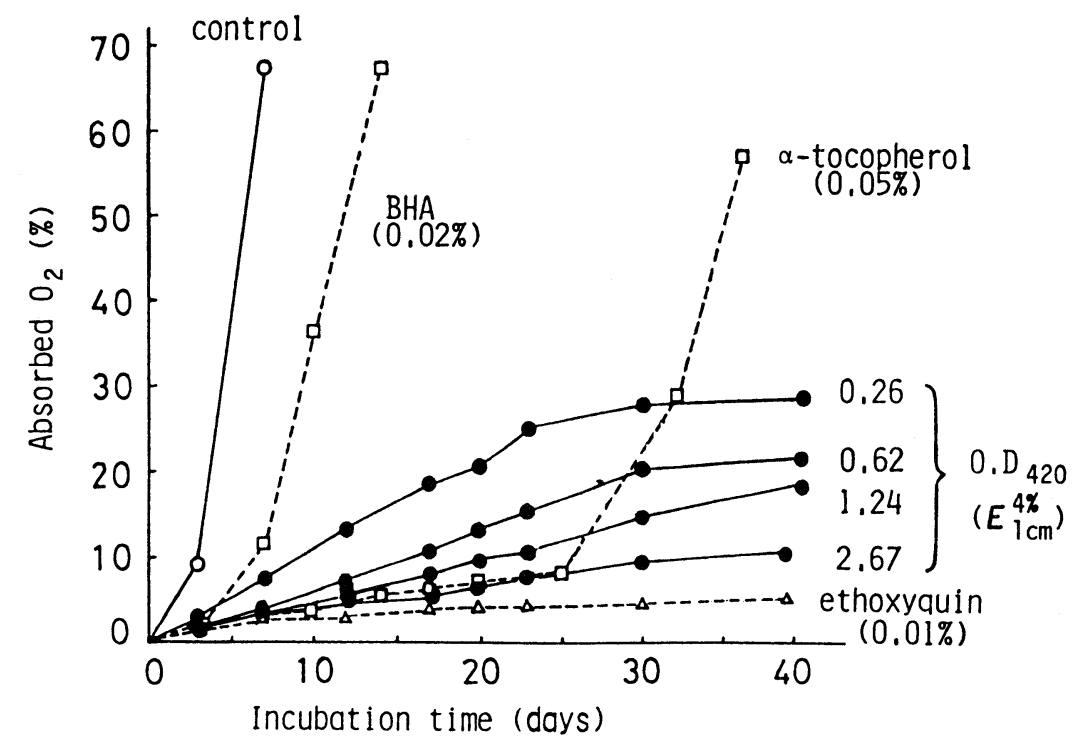

Fig. 19 Antioxidant Activity of Browned Stick Water on Sardine Oil. Sardine oil mixed with antioxidants or browned stick water with different absorbance was stored at $5^{\circ} \mathrm{C}$ in the dark.

提出した ${ }^{48)}$ 。

過酸化脂質を経口摂取した場合の影響については, 従 来から肝臟など多くの臟器に障害が出ることが知られて いるが，これらの実験はかなり多量の過酸化脂質を与え ていた。比較的少量の過酸化脂質でも長期間与えると胸 せん(腺)やひ(脾)臓などのリンパ系組織が選択的に障害

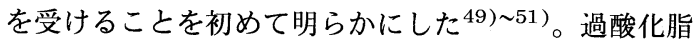
質の影響としては，ヒドロペルオキシドより炭化水素鎖 が解裂した低分子の二次生成物の影響が強かった ${ }^{52)}$ 。 これの結果は, 過酸化脂質が蓄積するような状態では, 免疫系が障害を受け, 感染症やがんになりやすいことを 示唆するものである。

\section{6 大豆油の戻り臭発生機構}

光酸化により大豆油が特異的に戻り臭を発生しやすい ことはよく知られているが，その機構は完全には解明さ れていない。大豆油から微量成分を除去し, 歩留まりを 下げて通常のトリアシルグリセリンのみをケイ酸カラム で調製すると, 酸化安定性は劣るものの戻り臭は発生し にくく, 微量成分の関与が明らかになった ${ }^{53)}$ 。大豆油 から単離した不けん化物には影響が認められず54)，ま たリポキシゲナーゼ欠損種でも戻り臭に差がないことか らリポキシゲナーゼは関与しないものと思われ ${ }^{55)}$, さ らにトリアシルグリセリン構造も関係なかった ${ }^{56) 。 一 ~}$ 方, 大豆油を分別すると特異な脂肪酸が結合したトリア シルグリセリンに原因があることが示唆され ${ }^{57)}$, 微量 成分として含まれるフラン酸の影響が大きいものと考え
られる58)。

\section{謝 辞}

本総説は筆者が東北大学農学部食糧化学科（現応用生 物化学科) で行ってきた研究をまとめたものであり, 学 会賞にご推蔗いただいた諸先生方に感謝申し上げます。 また，本研究をすすめるに当たって終始ご指導をいただ いた金田尚志博士 (東北大学名誉教授, 郡山女子大学教 授）と多くの共同研究者に感謝いたします。

（受付：1996 年 8 月 11 日, 受理 : 1996 年 11 月 12 日）

\section{文献}

1) K. Miyashita, K. Fujimoto, T. Kaneda, Agric. Biol. Chem., 46, 751 (1982).

2) K. Miyashita, K. Fujimoto, T. Kaneda, Agric. Biol. Chem., 46, 2293 (1982).

3) K. Miyashita, K. Fujimoto, T. Kaneda, Agric. Biol. Chem., 48, 2311 (1984).

4) K. Miyashita, N. Hara, K. Fujimoto, T. Kaneda, Lipids, 20, 578 (1985).

5) W. E. Neff, E. N. Frankel, K. Fujimoto, J. Am. Oil Chem. Soc., 65, 616 (1988).

6) K. Miyashita, N. Hara, K. Fujimoto, T. Kaneda, Agric. Biol. Chem., 49, 2633 (1985).

7) K. Miyashita, T. Chiba, K. Hata, K. Fujimoto, T.Kaneda, J. Jpn. Oil Chem. Soc., 34, 1029 (1985)

8) S.-Y. Cho, K. Miyashita, T. Miyazawa, K. Fujimoto, T. Kaneda, J. Am. Oil Chem. Soc., 64, 876 (1987).

9) S.-Y. Cho, K. Miyashita, T. Miyazawa, K. Fujimoto, T. Kaneda, Nippon Suisan Gakkaishi, 53, 
$813(1987)$

10) G. Hølmer, "Marine Biogenic Lipids, Fats and Oils Vol. 1", ed. R.G. Ackman, CRC Press, (1989) p.140.

11) R. G. Ackman, "Marine Biogenic Lipids, Fats and Oils Vol. 2", ed. R.G. Ackman, CRC Press, (1989) p.103.

12) H. Kimoto, Y. Endo, K. Fujimoto, J. Am. Oil Chem. Soc., 71, 469 (1994).

13) Y. Endo, H. Kimoto K. Fujimoto, Biosci. Biotech. Biochem., 57, 2202 (1993).

14) Y. Endo, S. Hoshizaki, K. Fujimoto, J. Am. Oil Chem. Soc., 73 (in press) (1996).

15) Y. Endo, S. Hoshizaki, K. Fujimoto, Biosci. Biotech. Biochem., 60 (in press) (1997).

16) Y. Endo, S. Hoshizaki, K. Fujimoto, J. Am. Oil Chem. Soc., 73 (in press) (1996).

17) T. Miyazawa, K. Fujimoto, T. Suzuki, K. Yasuda, Methods in Enzymology, 233, 324 (1994).

18) T. Miyazawa, M. Kikuchi, K. Fujimoto, Y. Endo, S.-Y. Cho, R. Usuki, T. Kaneda, J. Am. Oil Chem. Soc., 68, 39 (1991).

19) S.-Y. Cho, Y. Endo, K. Fujimoto, T. Kaneda, Nippon Suisan Gakkaishi, 55, 545 (1989).

20) S.-Y. Cho, Y. Endo, K. Fujimoto, T. Kaneda, Nippon Suisan Gakkaishi, 55, 541 (1989).

21) S. Mohri, S.-Y. Cho, Y. Endo, K. Fujimoto, Agric. Biol. Chem., 54, 1889 (1990).

$22)$ S. Mohri, S.-Y. Cho, Y. Endo, K. Fujimoto, J. Agric. Food Chem., 40, 573 (1992).

23) J.-H. Lee, K. Fujimoto, T. Kaneda, Nippon Suisan Gakkaishi, 47, 881 (1981).

24) J.-H. Lee, K. Fujimoto, T. Kaneda, Agric. Biol. Chem., 47, 2001 (1983).

25) J.-H. Lee, K. Fujimoto, T. Kaneda, Nippon Suisan Gakkaishi, 50, 1863 (1984).

26) K. Hasegawa, Y. Endo, K. Fujimoto, J. Food Sci., 57, 1123 (1992).

27) K. Hasegawa, Y. Endo, K. Fujimoto, Nippon Shokuhin Kogyo Gakkaishi, 40, 150 (1993).

28）遠藤泰志, 藤本健四郎, 食工誌, 40, 176 (1993).

29) 瀬戸美江, 藤本健四郎, 調理科学, 26, 102 (1993).

30) T. Chiba, M. Takazawa, K. Fujimoto, J. Am. Oil Chem. Soc., 66, 1588 (1989).

31) 千葉俊之, 藤本健四郎, 油化学, 40, 1011 (1991).

32) K. Hara, S.-Y. Cho., K. Fujimoto, J. Jpn. Oil Chem. Soc., 38, 463 (1989).

33) K. Hara, K. Hasegawa, Y. Endo, K. Fujimoto, J. Jpn. Oil Chem. Soc., 43, 57 (1994).

34) 藤本健四郎, 関 万德, 金田尚志, 食工誌, 21,86 (1974).

35）藤本健四郎, 菅野安弘, 金田尚志, 油化学, 29,419
(1980).

36) K. Fujimoto, T. Kaneda, Nippon Suisan Gakkaishi, 46, 1125 (1980).

37) K. Fujimoto, "Introduction to Applied Phycology", ed. I. Akatsuka, SPB Acad. Pub. (1990) p.199.

38) K. Fujimoto, T. Kaneda, Hydrobiologia, 116/117 : 111 (1984).

39) K. Fujimoto, H. Ohmura, T. Kaneda, Nippon Suisan Gakkaishi, 51, 1139 (1985).

40) K. Fujimoto, H. Ohmura, T. Kaneda, Agric. Biol. Chem., 50, 101 (1986).

41) S.-Y. Cho, A. Miura, K. Fujimoto, M. Inai, Nippon Suisan Gakkaishi, 54, 1017 (1988).

42) J. Y. Wang, K. Fujimoto, T. Miyazawa, Y. Endo, J. Agric. Food Chem., 39, 351 (1991).

43) J. Y. Wang, K. Fujimoto, T. Miyazawa, Agric. Biol. Chem., 55, 1531 (1991).

44) C.-C. Lin, K. Fujimoto, L. S. Hwang, Nippon Shokuhin Kogyo Gakkaishi, 40, 602 (1993).

45) K. Fujimoto, W. E. Neff, E. N. Frankel, Biochim. Biophys. Acta, 795, 100 (1984).

46) E. N. Frankel, W. E. Neff, D. D. Brooks, K. Fujimoto, Biochim. Biophys. Acta, 919, 239 (1987).

47) K. Hasegawa, K. Fujimoto, T. Kaneda, E. N. Frankel, Biochim. Biophys. Acta, 962, 371 (1988).

48) K. Hasegawa, K. Fujimoto, T. Kaneda, W. E. Neff, E. N. Frankel, Agric. Biol. Chem., 53, 1575 (1989).

49) M. Oarada, T. Miyazawa, K. Fujimoto, T. Kaneda, J. Nutr. Sci. Vitaminol., 34, 163 (1988).

50) M. Oarada, E. Ito, K. Terao, T. Miyazawa, K. Fujimoto, T. Kaneda, Biochim. Biophys. Acta, 960, 229 (1988).

51) M. Oarada, T. Majima, T. Miyazawa, K. Fujimoto, Biochim. Biophys. Acta, 1012, 156 (1989).

52) M. Oarada, T. Miyazawa, K. Fujimoto, E. Ito, K. Terao, T. Kaneda, Agric. Biol. Chem., 52, 2101 (1988).

53) Y. Endo, A. Saito, K. Fujimoto, T. Kaneda, J. Jpn. Oil Chem. Soc., 37, 291 (1988).

54) Y. Endo,' J. Chiba, K. Fujimoto, T. Kaneda, Nippon Shokuhin Kogyo Gakkaishi, 36, 682 (1989).

55) Y. Endo, H. Endo, K. Fujimoto, K. Kitamura, $J$. Jpn. Oil Chem. Soc., 39, 618 (1990).

56) 遠藤泰志, 藤本健四郎, 喜多村啓介, 食工誌, 38,930 (1991).

57) Y. Endo, H. Endo, K. Fujimoto, T. Kaneda, J. Am. Oil Chem. Soc., 68, 769 (1991).

58) 西村 猛, 遠藤泰志, 藤本健四郎, 横溝和久, 第 34 回 油化学討論会講演要旨集, (1995) p. 185. 


\title{
日本油化学会誌本号掲載 論文要旨
}

[総説 ]

\section{油脂および油脂食品の酸化的劣化と その評価法に関する研究}

\author{
藤 本 健四郎 \\ 東北大学農学部応用生物化学科 ( 于981 仙台市青葉区堤通雨宮町 1-1)
}

ヒドロペルオキシドは不飽和脂質酸化の第一次生成物であるが，高度不飽和脂肪酸含有脂質のように脂質の種類 によっては，ヒドロペルオキシドの安定性が悪く，容易に二量体などの二次生成物に分解することがある。このよ うな脂質が夕ンパク質など反応性の高い成分と共存すると, 脂質酸化が進行しても少量のヒドロペルオキシドしか 蓄積しない。従って，このような脂質や食品においては，脂質酸化による劣化を評価するに当たっては，過酸化物 の定量は不適であり，二次生成物あるいは夕ンパク質と結合した蛍光物質のような安定な最終生成物の測定が望ま しい。高度不飽和脂肪酸含有トリアシルグリセリンの酸化安定性は, トリアシルグリセリン分子構造, なかでも 1 分子中の高度不飽和脂肪酸モル数に依存した。

(連絡者: 藤本健四郎) Vol. 46, No. 3, 249 (1997).

\section{［報文］＼cjkstart糖脂質酵素モデル（第 11 報）}

\section{加水分解酵素モデルとしての糖脂質の活性点の探求}

\author{
大勝 靖一・洼小谷淳一・堀辺美香子 \\ 工学院大学工学部応用化学科 (于163 東京都新宿区西新宿 1-24-2)
}

合成糖脂質は加水分解酵素モデルとして報告されており，その活性点は糖残基の 2,3 -位のヒドロキシル基に帰 せられると推定されている。本論文では, 糖性を示すことを見いだし, またその共役塩基が加水分解活性と関係の あることを確認した。ついで2-または 3-デオキシ糖脂質を合成し，フェニルアラニン $p$-ニトロフェニルエステル

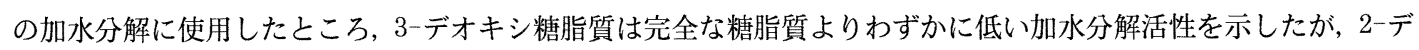
オキシ糖脂質はかなり低い活性しか示さなかった。これらの結果から，3-位のヒドロキシル基も弱い活性点として 作用するけれども，2-位のヒドロキシル基が主たる活性点であると結論できた。従って, 糖残基の 2-位のオキシ アニオンがエステルのカルボニル炭素を求核的に攻撃し，その結合を開裂するものと推定される。

(連絡者: 大勝靖一) Vol. 46, No. 3, 261 (1997).

\section{[報文 $]$ 糖脂質酵素モデル（第 12 報） \\ アミノ酸エステルの加水分解に及ぼす反応場の影響}

大 勝 靖 一・斎 藤 幸 平

工学院大学工学部応用化学科 ( ₹163 東京都新宿区西新宿 1-24-2)

糖脂質加水分解酵素モデルを用いるアミノ酸エステルの加水分解反応において, リン脂質の, 反応場としての添 加効果を検討した。リン脂質は, 3 つの種類, すなわち飽和疎水性アルキル鎖 (相転移温度, $60.0 \sim 86.9^{\circ} \mathrm{C}$ ), 適度 に不飽和のアルキル鎖 $\left(-4.4 \sim-5.8^{\circ} \mathrm{C}\right)$, 高度に不飽和のアルキル鎖 $\left(-24.2 \sim-25.2^{\circ} \mathrm{C}\right)$ を有するリン脂質に分類で きた。糖脂質の加水分解活性は, リン脂質の種類に依存した。その活性は飽和リン脂質(ゲル状態)の存在下に抑制 され, 一方不飽和リン脂質（液晶状態）を, 特に $60 \mathrm{~mol} \%$ 以上の濃度で用いることにより増大した。これは, 液 晶状態での基質の取り込み速度の増大によって説明できた。さらに, 不飽和りン脂質は, 糖脂質によるアミノ酸の 種類の識別をも向上させた。従って, 加水分解酥素モデル系において, 不飽和リン脂質を用いることにより, 高加 水分解速度と基質識別ひ両方を向上させうることができた。 (連絡者: 大勝靖一) Vol. 46, No. 3, 271 (1997). 